\title{
A method to evaluate downy mildew resistance in grapevine
}

\author{
S. Boso*, J.L. SANTIAGO, M.C. MARTíneZ \\ Misión Biológica de Galicia, Consejo Superior de Investigaciones Científicas, Apartado correos 28, 36080 Pontevedra, España
}

(Received 5 August 2004; accepte 21 October 2004)

downy mildew / Plasmopara viticola / leaves / image analysis / Vitis vinifera

\section{INTRODUCTION}

Downy mildew, caused by Plasmapora viticola, is one of the endemic cryptogamic diseases of northern Spain that most commonly affects grapevines. Indeed, it is one of the diseases best known to viticulturalists worldwide. When climatic conditions are favourable, it attacks all organs of the plant, causing very serious crop losses and affecting the profitability and cost of wine. Given the climatic conditions of northern Spain, downy mildew attacks occur every year without exception, obliging growers to apply several treatments during the vine growth cycle. This not only increases cultivation costs enormously but causes environmental pollution and leads to problems during the fermentation of the must.

Although the economic losses caused by downy mildew can be severe, greater knowledge of the pathogen's biology, the availability of systemic treatments, and the better training of growers have helped reduce the risk of such damage. In recent years, several integrated programmes have been launched in the fight against this disease. Taking into account climatic conditions, the point in the vine growth cycle, and the development of the fungus, the aim is to reduce the number of treatments that need be applied to a minimum. Wine-producing countries are trying to develop disease prediction models for each of their growing regions. The German "Pro" [6] \& "Freiburg" [8] models, and the Swiss "Winemild" model [1] are among the most well known.

Infection with Plasmapora viticola leads to different symptoms depending on the organs attacked and the stage of its development: young leaves, adult leaves, or flowering stage, veraison, or ripening. Although the leaves can be affected even when very small, maximum sensitivity occurs when they are about $3 \mathrm{~cm}$ in diameter. The first symptoms are seen on the leaf lamina as 'oil spots'. In the last phases of leaf disease, these spots become reddish-brown and acquire a typical mosaic pattern. Leaves become less sensitive as they age [3]. Vitis vinifera L. is very sensitive to downy mildew $[4,5,10]$, although there are differences between different varieties and possibly even between different clones [10]. Many authors [4, 10,7,11] have reported that several factors appear to determine the degree of resistance possessed.

Several laboratory studies [12] have investigated the resistance of different varieties of vine to downy mildew, but such results cannot always be extrapolated to the field. Different climatic, soil and cultivation conditions, etc., can all have great influence on whether the disease will appear and how it will develop. The qualitative methods currently used to measure resistance to disease have the problem of inherent subjectivity $[5,12]$. A method is therefore required that can quantify the resistance of different varieties and clones in the field, which takes into account the factors that affect both plant and pathogen development, and which reduces as much as possible the subjectivity of current methods.

\section{RESULTS AND DISCUSSION}

Some of the most noticeable symptoms of this disease are different types of spots on the leaves. A method was therefore designed to quantify plant resistance using image analysis to determine the number of spots on each leaf, the surface area occupied by each, and therefore the total surface area occupied per leaf. This method was tested over a period of three years (2001, 2002 and 2003) in a vineyard $4 \mathrm{~km}$ from the city of Pontevedra (northwest Spain), and during 2002 and 2003 in another vineyard with a very particular microclimate some $60 \mathrm{~km}$ south of Pontevedra. The difference in climate allows grapes of any variety to ripen at least 15 days earlier in the latter vineyard. Both vineyards are approximately 1 ha in area and were randomly planted with different clones of the variety Albariño (10 plants of each type). These clones, which were ten years old, were perfectly differentiated and grown en espalier. Meteorological stations were positioned at both vineyards, and provided daily temperature, rainfall and humidity data.

\footnotetext{
* Corresponding author: susanab@mbg.cesga.es
} 
Table I. Mean values of each clone for severity and intensity of leaf infection at sampling times S1 and S2, and average.

\begin{tabular}{|c|c|c|c|c|}
\hline Clones & From & Years & $\begin{array}{l}\text { Severity } \\
\mathrm{S} 1+\mathrm{S} 2^{\mathrm{a}}\end{array}$ & $\begin{array}{c}\text { Intensity } \\
\text { S1+ S2 }\end{array}$ \\
\hline & & & Mean $(D . S)^{\mathrm{c}}$ & Mean (D.S) \\
\hline \multirow[t]{4}{*}{ A } & North & 2001 & $0.145(0.09)$ & $0.063(0.03)$ \\
\hline & & 2002 & $0.060(0.01)$ & $0.304(0.17)$ \\
\hline & & 2003 & $0.174(0.08)$ & $4.447(1.20)$ \\
\hline & & Mean ${ }^{b}$ & $0.126(0.06)$ & $1.604(0.460)$ \\
\hline \multirow[t]{4}{*}{ B } & & 2001 & $0.175(0.1)$ & $0.092(0.01)$ \\
\hline & North & 2002 & $0.038(0.02)$ & $0.752(0.20)$ \\
\hline & & 2003 & $0.168(0.08)$ & $0.730(0.30)$ \\
\hline & & Mean $^{\mathrm{b}}$ & $0.127(0.06)$ & $0.524(0.17)$ \\
\hline \multirow[t]{4}{*}{$\mathrm{C}$} & & 2001 & $0.120(0.08)$ & $0.146(0.09)$ \\
\hline & North & 2002 & $0.012(0.01)$ & $0.612(0.20)$ \\
\hline & & 2003 & $0.095(0.01)$ & $0.414(0.25)$ \\
\hline & & Mean $^{\text {b }}$ & $0.075(0.03)$ & $0.388(0.18)$ \\
\hline \multirow[t]{3}{*}{1} & & 2002 & $0.027(0.01)$ & $0.605(0.25)$ \\
\hline & South & 2003 & $0.322(0.30)$ & $0.388(0.003)$ \\
\hline & & Mean $^{\mathrm{b}}$ & $0.174(0.10)$ & $0.496(0.12)$ \\
\hline \multirow[t]{3}{*}{2} & & 2002 & $0.117(0.08)$ & $1.119(0.10)$ \\
\hline & South & 2003 & $0.413(0.44)$ & $0.313(0.003)$ \\
\hline & & Mean $^{\mathrm{b}}$ & $0.264(0.26)$ & $0.716(0.05)$ \\
\hline \multirow[t]{3}{*}{3} & & 2002 & $0.081(0.02)$ & $0.677(0.20)$ \\
\hline & South & 2003 & $0.278(0.28)$ & $1.220(0.003)$ \\
\hline & & Mean $^{\mathrm{b}}$ & $0.180(0.15)$ & $1.639(0.10)$ \\
\hline \multirow[t]{3}{*}{$\operatorname{LSD}_{0.05}$} & & 2001 & 0.060 & 0.120 \\
\hline & & 2002 & 0.152 & 0.080 \\
\hline & & 2003 & 0.036 & 0.020 \\
\hline
\end{tabular}

${ }^{\text {a }}$ S1: first sampling time; S2: second sampling time.

${ }^{b}$ Mean: average of years.

${ }^{\mathrm{c}}$ D.S.: standard deviation.

Simple observations made over a number of years had already revealed considerable differences between the clones with respect to mildew resistance (Tab. I). Up to the time of the study, downy mildew attacks had occurred every year without exception; there was, therefore, no need to inoculate the crops with the pathogen before the proposed method could be tested.

In northwest Spain, the severe downy mildew attacks that occur every year sometimes cause the complete defoliation of infected plants. Our intention was to test the method over consecutive years, but during the first year the plants were provided with no protective treatment and became so deteriorated that it was impossible to repeat the study the following year. Therefore, five representatives of each of the clones in each vineyard were treated with fungicide (and kept in perfect condition) and five were left untreated. Thereafter, the plants sampled were those that had been left in reserve from the year before, while those treated were the ones that had been sampled the year before.

Sampling was undertaken at two different times:

- first, when the primary symptoms (oil spots) reached an incidence of 60-70\% in the majority of clones (incidence was defined as the number of infected leaves on each clone/total number of leaves on the clone),

- and second, when more than $60 \%$ of the leaves affected in the first sampling showed secondary or tertiary infection (mosaics of spots).

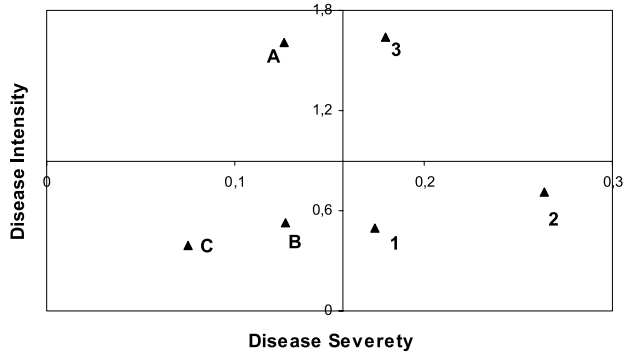

Figure 1. Mean values of disease intensity and severity for the 3 years of the study, combining the two sampling times.

These two samplings allowed the development of the disease to be followed over the plant growth cycle and with respect to the climatic conditions of each year. They also showed whether plants were more susceptible to early or late attack.

Samplings were performed as follows. Fifty adult leaves with symptoms of downy mildew infection were randomly selected from the five representatives of each clone studied. These leaves came from the basal, medial and apical parts of the vine shoots: previous work [2] had confirmed the results obtained by Mansilla et al. [9], who indicated that the first oil spot can appear anywhere on the plant. During the first sampling, each leaf was marked with tiny tags, numbered $1-50$, 


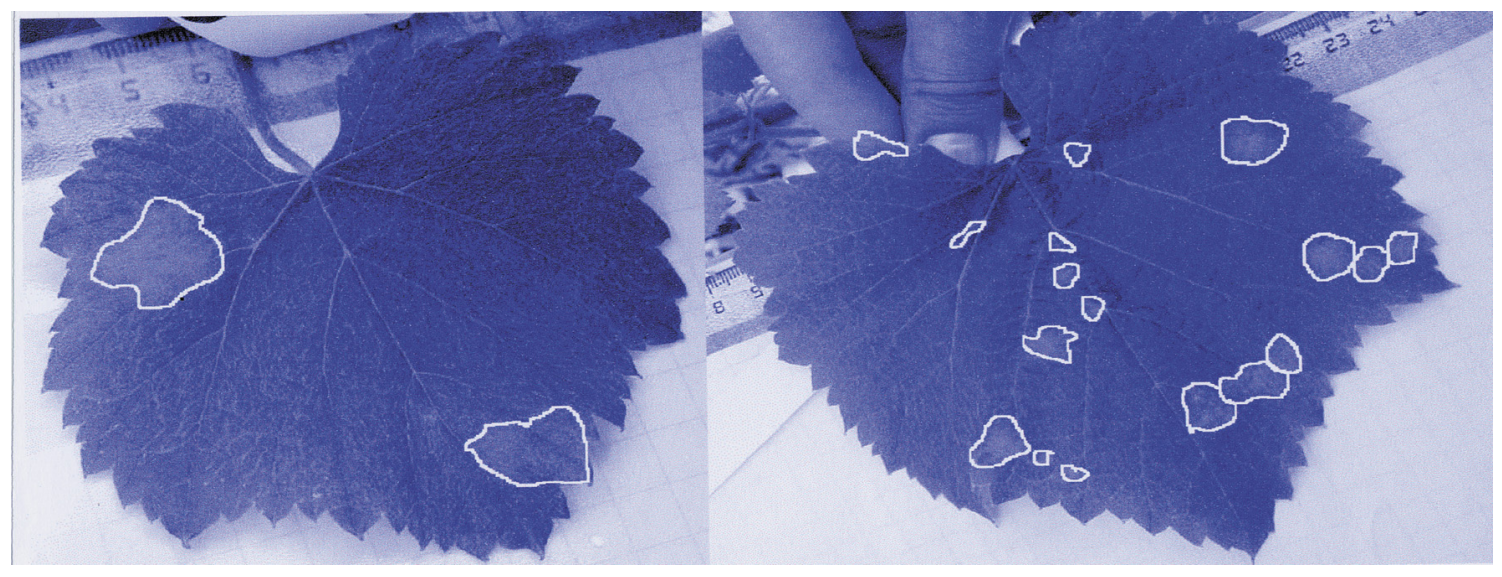

Photographs 1. Leaves photographed revealed considerable differences between clones. Leaves with few spots (A) and many small spots (B).

attached to the peduncle. Without removing the leaves (in order to interfere as little as possible with both plant and pathogen development), photographs were taken of every one using a digital camera. A reference scale was included in each to be able to compare the different leaves. These photographs were then downloaded into a computer and an image analysis program (análySIS 3.0) was used to determine the number of spots on each leaf, the area of each spot, and therefore the total surface area they occupied per leaf (Photographs 1).

From these data, the following relationships were calculated for each leaf:

Severity of leaf infection: sum of the surface of all spots / leaf surface area.

Intensity of leaf infection: number of spots on each leaf / leaf surface area.

Incidence of leaf infection: number of leaves diseased per vine / total number of leaves per vine.

Statistical Analysis. These ratios were analysed by analysis of variance and the least significant difference (LSD) method $(P<0.05)$ to see if there were any significant differences between the clones with respect to each variable.

These analyses confirmed that those clones which to the naked eye seemed most sensitive or most resistant were, in fact, just that. It was also found that some clones were more sensitive to early attack but were more resistant to later attacks, while others were sensitive to both, more resistant to both, or were more resistant to early attack but more sensitive to later attacks (Fig. 1). These results were maintained from one year to the next, i.e., the most sensitive or resistant clones were the same every year, irrespective of the reigning climatic conditions.

\section{CONCLUSION}

This method can be used with both vine clones and varieties, and could even be used with other species and other diseases (as long as the symptoms include different types of spots on the leaves). In fact, we have used this method successfully to quantify vine resistance to Powdery mildew and Botrytis. This method allows one to clearly and objectively identify and quan- tify clones or varieties with greater resistance to cryptogamic diseases. The method worked perfectly in the two vineyards studied. The only difference was the time when the sampling had to be performed, due to the shorter disease cycles caused by the climate of the vineyard south of Pontevedra. Over the three consecutive years of the study, the sampling date varied because of the climatic conditions, but the results obtained did not.

\section{REFERENCES}

[1] Blaise P., Gessler C., On the search for an applicable forecasting model of downy mildew epidemics on vines in Switzerland, Bull. OILB/SROP 13 (1990) 187-190.

[2] Boso S., Estudio sobre el nivel de resistencia a mildiu, oídio y botrytis, en distintos clones de la variedad albariño (Vitis vinifera L.), y sus características agronómicas, Tesis de Licenciatura, Facultad de Biología, Universidad de Vigo, 2002.

[3] Dubos B., Maladies cryptogamiques de la vigne, Champignons parasites des organes herbacés et du bois de la vigne, Éditions FéretBordeaux, 2002.

[4] Föex G., Cours complet de Viticulture, $3^{\mathrm{e}}$ ed. G. Masson (Ed.), Paris, 1891.

[5] Galet P., Précis de Pathologie viticole, $2^{\mathrm{e}}$ ed., Imprimerie JF Impression, Montpellier, 1995.

[6] Hill G., Plasmopara risk Oppenheim, a deterministic computer model for the viticultural extension. Atti del convegno (Modelli euristici e operativi per la difesa integrata in agricultura), Caserta 1 (1990) 182-194.

[7] Huglin P., Biologie et écologie de la vigne, Ed. Payot, Lausanne, Paris, 1986.

[8] Kassemeyer H.-H., Experience with electronic warning of downy mildew grapevine, Proceedings of the first International Workshop on grapevine downy mildew modeling Geneva, New York, USA, August 1991, Gadoury D.M., Seem R.C. (Eds.), p. 80.

[9] Mansilla Vázquez J.P., Pérez Otero R., Lucha oportuna contra el mildiu de la vid, Viticultura / Enología Profesional 44 (1996) 2432.

[10] Ravaz L., Le mildiou, Masson Ed., Paris, 1914.

[11] Reynier A., Manual de Viticultura, $4^{\circ}$ ed., Ed. Mundi-Prensa, Madrid, 1989.

[12] Staudt G., Kassemeyer H.-H., Evaluation of downy downy mildew (Plasmopara viticola) resistance in various accessions of wild Vitis species, Vitis 34 (1995) 225-228. 